\title{
THE SENTIMENTAL
}

NOVEL AND THE

\section{REPUBLICAN IMAGINARY: SLAVERY IN PAUL AND VIRGINIA}

\author{
ANNA NEILL \\ William Ray. STORY AND HISTORY: NARRATIVE AUTHORITY AND SOCIAL \\ IDENTITY IN THE EIGHTEENTH-CENTURY FRENCH AND ENGLISH \\ NOVEL. Oxford: Basil Blackwell, 1990.
}

In Story and History, William Ray describes the progress of the novel as the fashioning of private desires and "natural" sentiments into an exemplary collectivity. Novels are modern not only in their fidelity to sense perception and the particulars of human experience, as Watt's Rise of the Novel has shown, but also in the capacity they have to shape that reality by their regulation of affect. Ray shows how in eighteenth-century critical commentary it is the moral consequences of history that are given the most emphasis-the way in which historical and fictional discourses operate upon the world so as in part to produce the very social practices of which they are an expression. In the case of the novel this involves the transformation of private histories into exemplary narratives in such a way that private accounts of the self and the particular affective relations they produce can participate in a sense of shared cultural history. Crucial to this model, however, is the way in which the novel's faithfulness to sentimental particularities allows it to remain naive to its own production of authority: "every articulation of reality ... is enabled by, and subject to, grammars it cannot understand... The novel can exercise authority even as it denies it" [16]. Our sense of a moral authority is transmitted through the novel as though it were something entirely felt.

The exemplary narrative is characteristically one where a private history comes into conflict with the existing order and becomes the "[model] for a reconfiguration of collective values." The moral arbitration of this conflict at the level of plot is often in turn validated by the authority of the moral interpreters "outside" the text: The "Author" (or "Editor") and "Reader." What Ray describes as the displacement of personal narration by professional narrative thus coincides with the reformation of the reading community in the production of an exemplary audience. One of the crucial figures for Ray in this articulation of moral community in the novel is Rousseau. In Julie, Ray argues, a narrative of resistance to the old order (represented by a tyrannical father) unexpectedly rejects the romance themes of thwarted love and filial rebellion. In their place the novel conducts a reconciliation of nature and social authority as the law of the family comes to

I would like to thank Mary Jacobus, Neil Saccamano, and Stephen Turner for their help with earlier versions of this article. 
prevail over both the absolute regime of the father and the reckless impulses of the heart. Those rebel passions which provide the substance of the first half of the novel are transformed in the second into the social virtues that characterize the model community at Clarens. Yet significantly, Ray argues, the lessons of this conversion are principally for reading. Cultural proprieties are articulated not by literary convention but rather by a moral exemplarity whose representation in Wolmar and Julie the epistolary narrative itself mimics in the education of its readers. "Rousseau's" prefaces to and shaping of the letters at once asserts his editorial authority and relinquishes it as the mark of historical transparency: "He wants the story to function like history, indeed to become history, while remaining his" [253].

I open with Ray's argument about Rousseau because this theory of a new "novelistic" authority offers a way of reading Rousseau's political writings that links the tropes of sentimentalism with contemporary republican theory. For Rousseau, sentimental history both offers a narrative of the passions that have corrupted man out of the state of nature and at the same time demands a republican reordering of these events of the heart whereby social relations will be turned over to the authority of the general will. The double movement of sentimental reading (in to the private intuitions performed by the sentimental gesture and then out to the ideal state formed by collective experience), I want to argue, has a peculiar force in the context of colonialism. My focus will be on the representation of the slave colony in Bernardin de Saint-Pierre's Paul and Virginia. Here the novelistic ordering of the passions and the production of the ideal state are drawn into history by the fact of this state being a colony of France, and hence both a satellite of European republican fantasy and an infant society whose historical and sentimental ties to its parent state make it the ideal context for the staging of a literary old-world melancholy. Conspicuously absent, however, from this historicized, sentimental "republic" (yet central to the history and "progress" of the colony itself) is the figure of the slave. It is in the dialogue between republican imaginary and sentimental event that slavery is erased from the novel's colonial memory.

It is difficult to know how to read Paul and Virginia. A story of innocent childhood love on a remote island, it seems at first rather generically at odds with the "worldliness" of contemporary sentimental novels. Indeed, in its effectual sealing off of an idealized rural existence from the corruptions of contemporary Europe it is pastoral. ${ }^{1}$ Paul and Virginia "believe[ ] that the world ends at the limits of their island"; "What has taken place long ago and in far-away countries trouble[s] them not at all" [PV 47]. When Virginia begins to awake to her own sexuality and is banished to France, the pastoral hideaway is suddenly exposed to European evils in the form of Virginia's aging, selfish aunt, whose efforts to "Parisianize" her niece lead ultimately to the tragedy of the latter's death. Yet this seems less a sign that the outside world is powerfully intrusive on the Arcadian one than a marker of the difference between the two, indicating that the new society is morally distinct from its parent nation and that by virtue of its separateness it can criticize a degenerate Europe: For Virginia, France is "a country of savages" [94]. The novel seems to offer a kind of pastoral suspension of worldly influences not least by its allegorizing of them. The death

1. See Goodden, "Tradition and Innovation in Paul et Virginia." Goodden argues that the pastoral characteristics, including the use of Virgilian similes and the Theocratian setting, are manifestations of a Rousseauean distaste for modern civilization (a point I take up later). She does point out, however, that rococo pastoralism is countered by the precise historical circumstances the novel describes, particularly the fact of Mme de la Tour's exile in Mauritius (the effect of social disapproval rather than natural disaster). 
of Virginia, we are told at the end of the novel, is more than a family tragedy: "She has suffered the fate reserved for birth, for beauty, for empires themselves" [129]. Her death, closely followed as it is by those of all the other members of her immediate communityPaul, Marguerite, Madame la Tour, and the slave couple Marie and Domingue-marks the final sealing off of this Arcadia from the old world as it allegorizes the dangers of European cultural expansion, particularly the exportation of corrupt morals. The pressure of the outside, civilized world can literally invade and destroy this society of nature, but only by allowing for the assumption of that very community into pastoral memory: "Their shades have no need of the celebrity that they shunned in life; but if they concern themselves still with what happens on earth, no doubt they choose to wander beneath the thatched roofs that shelter laborious virtue" [136].

Yet there are ways, more urgently, in which the pastoral is undone by a sentimentalism that opens the novel up to the very world on which it seeks to provide a corrective commentary. This is to suggest first that the sentimental turn involves a growing into political consciousness on the part of this narrative - a melancholy awareness of the ways in which the contradictions between colony and ideal political state precipitate a fall out of pastoral romance. In the second place, the novel itself (as the instrument of "civility") tries to shape these troubling eruptions of history into a coherent moral project-one whereby the circulation of unhappy stories can turn reading into an activity of sympathetic bonding. Sentimental reading, then, secures a society of tears, whose collective imaginary can restore the strong narrative of moral order to the weaker one of political confusion.

A precise historical and geographical setting (the Mauritius of 1726 and after) inevitably locates the novel in contemporary debate about slavery in the French colonies. Mauritius was annexed by the French in 1715 and renamed the lle de France. In 1722 the first significant settler parties arrived. Under the administration of Mahe de La Bourdonnais (1735-46), the settler population was consolidated and the project of importing slaves from Portuguese East Africa (where they had previously been taken from Madagascar and the African mainland) was introduced as a means of improving the sugar and mining industries on the island. ${ }^{2}$ It then remained under French control until 1810, when the French possessions were handed over to Britain. Background details in the novel, from the figuring of Bourdonnais as the mediator between France and the colony-he facilitates Virginia's departure for Paris and lectures Paul on the nature of political corruption-to the climactic sinking of the Saint Géran, are faithful enough to recorded events that they bring the pastoral narrative into historical focus. Interestingly, in its opening pages, the novel makes it clear that the tension between pastoral utopia and political event will not be resolved in allegory. The author's preface begins as a kind of apology for pastoral innovation: "Our poets have for long enough made their lovers rest on the banks of streams, in meadows and beneath the leaves of beeches. Mine were to sit on the seashore, at the foot of high rocks, in the shade of coconut-palms, banana-trees and lemon-trees in flower" [37]. Yet within the space of a few lines the self-authorizing gesture has become one based less on adjustments in generic convention than on the relationship of fictional narrative to historical truth: "I can assure the reader that those I speak of did really exist, and that their story is true so far as its principal events are concerned. Several settlers whom I knew on the lle de France testified to their authenticity."

2. For further detail see Nwulia, The History of Slavery in Mauritius and the Seychelles [ch. 1, "Before 1810" 17-28]. A more general discussion of slavery in the European colonies and its relationship to abolitionist sentiment at home can be found in David Brion Davis, The Problem of Slavery in the Age of Revolution [ch. 1, "What the Abolitionists Were up Against" 39-84]. 
More significant, perhaps, than historical setting, the date of the novel's publication (1788) coincides with a climax in abolitionist sentiment in France. While, in the lle de France, restrictions on the rights of slaves had been consolidated by the Ordinance of 1767 and the code noir ${ }^{3}$ of 1723, in France just prior to and during the Revolution, opposition to the trading and ownership of slaves was becoming increasingly audible. Despite the success of white colonist representatives in preventing political debate on the trade, ${ }^{4}$ the increase in abolitionist pressure on both sides of the English channel, combined with the slave uprising in Saint Domingue in 1791, eventually forced the Assembly in 1794 to outlaw slavery in the empire. ${ }^{5}$ What is perhaps most curious about Paul and Virginia is the way in which, particularly in view of Saint-Pierre's own abolitionist sympathies, the slavery debate is elided. Just why the politics of slavery should remain so obscured in the novel while other pressures, both internal (the threat of female sexuality) and external (the European influence), are allowed to intrude on the Arcadia remains unclear.

Despite her recent loss of both husband and livelihood, Mme de la Tour has the spirit of a Crusoe: "The island was almost uninhabited then and land to be had for the taking" [41]. It is this "almost" that revivifies the dim but problematic figure of Friday, although in this case it is not the indigenous peoples who are only half-acknowledged but rather the imported slave population together with the established settler community that manages it. Between them, and with the help of the narrator, Mme de la Tour and her companion Marguerite divide up the valley they inhabit. Their labors and those which fall later to their children, we are told, are of the most "natural" kind. The fact that it is the "unremitting labour of the slaves" [44] that builds and develops the plantation does not seem to complicate the notion that tasks fall by nature to their subjects. Indeed the pleasure Domingue ("Marguerite's Yolof Negro") takes in laboring is, the narrator insists, the product of his attachment to the community he serves and whose sentiments he mimics: "He performed all these tasks with intelligence and energy because he was eager to serve. He was strongly attached to Marguerite and hardly less so to Madame de la Tour, whose Negress he had married when Virginia was born. She was called Marie and he loved her passionately" [44]. Similarly, when expressions of collective sympathy are summoned to dispel any signs of dejection in the "little society" [65], we are assured that "even Marie and Domingue would lend their aid." Where the novel opens with the slave woman as silent, anonymous other, a figure who cannot offer Mme de la Tour companionship for the very reason that her position is at such a sympathetic remove from the Frenchwoman's own, it is in the naming of the slave couple that both their own love bond and their pseudoabsorption into the French community are allowed. "All would grieve if they saw one grieving," the narrator continues, "and weep if they saw him weep." In this way the slave population is contained by the sentimental "little society," which can transform the threat of an outside abolitionist pressure into a localized exchange of sympathies.

3. The code noir was the popular name for a royal edict that forbade intermarriage "under pain of punishment and arbitrary fine." Whites were also forbidden to have slave concubines [Nwulia 29]. The ordinance expanded in the 1723 edict to forbid trade between slaves; to prohibit their gambling; to impose the death penalty on any slave who struck his owner or his owner's family and severe physical punishments (usually flogging) on fugitive slaves and thieving [30-34].

4. Local resistance to abolition in the Ile de France was substantial. By 1798 the number of slaves was four times that of the number of free residents living on the island, and the setlers feared that antislavery sentiment in France might fuel a rebellion in the colony. See Biondi and Zuccarelli, 16 Pluviose An II [26-27; 78-79].

5. Of course while the revolutionary ideals of liberty and equality easily accommodated abolitionist and anticolonial sentiment, the edict against slavery was as much the product of political pragmatism as of egalitarian spirit. The abolition order in Saint Domingue, for example, had perhaps more to do with the difficult distractions of the war with England than it did with sympathy for the slave's insurrection of 1791. See Benot, La Révolution française [7-8]. 
This controlling of dangerous or problematic inequalities by the little community together with the sense of a sentimental worldliness that disturbs the "natural" Arcadia are, I would like to argue, functions of a social contract that tries to overcome the problem of social and political inequality with what Ray describes as a newly authorized order of virtue. For Rousseau, the development of society out of a state of nature is motivated by something I would like to call the "republican imaginary"-a notion of the ideal state, which can resist the corrupting and divisive forces of economic and social progress. In the spirit of "unmediated" authority established so successfully by the novel, the republican imaginary endeavors to produce a sentimental citizen, a subject whose sense of duty to the state is in harmony with the impulses of his heart.

Rousseau's Discourse on the Origin of Inequality describes how civilization and progress have been the ruin of the human race. For Rousseau, inequality does not exist in a state of nature. Savage life is characterized by simplicity and uniformity [Discourse 58], whereas slavery and domination are not natural states but the products of the mutual dependencies between men brought about by the institutions of society. It is only with the division of labor and the cultivation of land as property that the social contract becomes necessary; political (and thence civil) distinctions are established, and "the bonds of servitude" are formed. Civilized man progresses at the expense of natural liberty.

As Rousseau himself admits, however, the notion of a pure state of nature can only ever be hypothetical: "For it is no light undertaking to separate what is original from what is artificial in the present nature of man, and to have a proper understanding of a state which no longer exists, which perhaps never existed, [and] which perhaps never will exist" [34]. The only natural principles that can be observed "prior to reason" are those of self-preservation and a natural pity, which in the state of nature "takes the place of laws, mores, and virtue" [55]. Yet while natural society can never be much more than an "imaginary conjecture[]" [40], its very philosophical invisibility is what allows Rousseau to construct as "true history" the narrative of a fall into inequality. A Hobbesian "state of nature," he argues, is already inside this history in that it depicts civil rather than natural man, the subject already of "authority" and "government" even as it identifies the power of the stronger over the weaker [38]. It is the philosophical fact of this already being inside history that, I argue, enables literary sentimentalism. Civil Society is to be understood not only as the history of the progress of inequality but also as the history of developments of the heart and of the way in which these inequalities are legitimated under the laws of conjugal and paternal love.

Society and government, Rousseau corrects Hobbes, do not begin with arbitrary power, "which is but their corruption and extreme limit, and which finally brings them back simply to the law of the strongest, for which they were initially to have been the remedy" [74]. What Hobbes fails to recognize is that political authority originates with the institution of property (in this context the claiming of colonial territory) and develops alongside the forces of technological progress, social commerce, and the division of labor. There is a kind of double movement here. On the one hand the inevitable progression out of nature and into civil society brings about a competition of desires and a growing imbalance in the distribution of wealth and happiness. Society divides itself into strong and weak, rich and poor. On the other hand, this drawing of man out of his natural uncivilized state determines, at least during the youthfulness of civil society, the setting up of sympathetic communities or "little societies" (petites sociétés) (the phrase is the same as Saint-Pierre's), of which the family is the best example. Here husbands and wives, fathers and children are united by mutual attachment and a shared sense of need. It is in this little society, where authority is closest to love, that republican and sentimental 


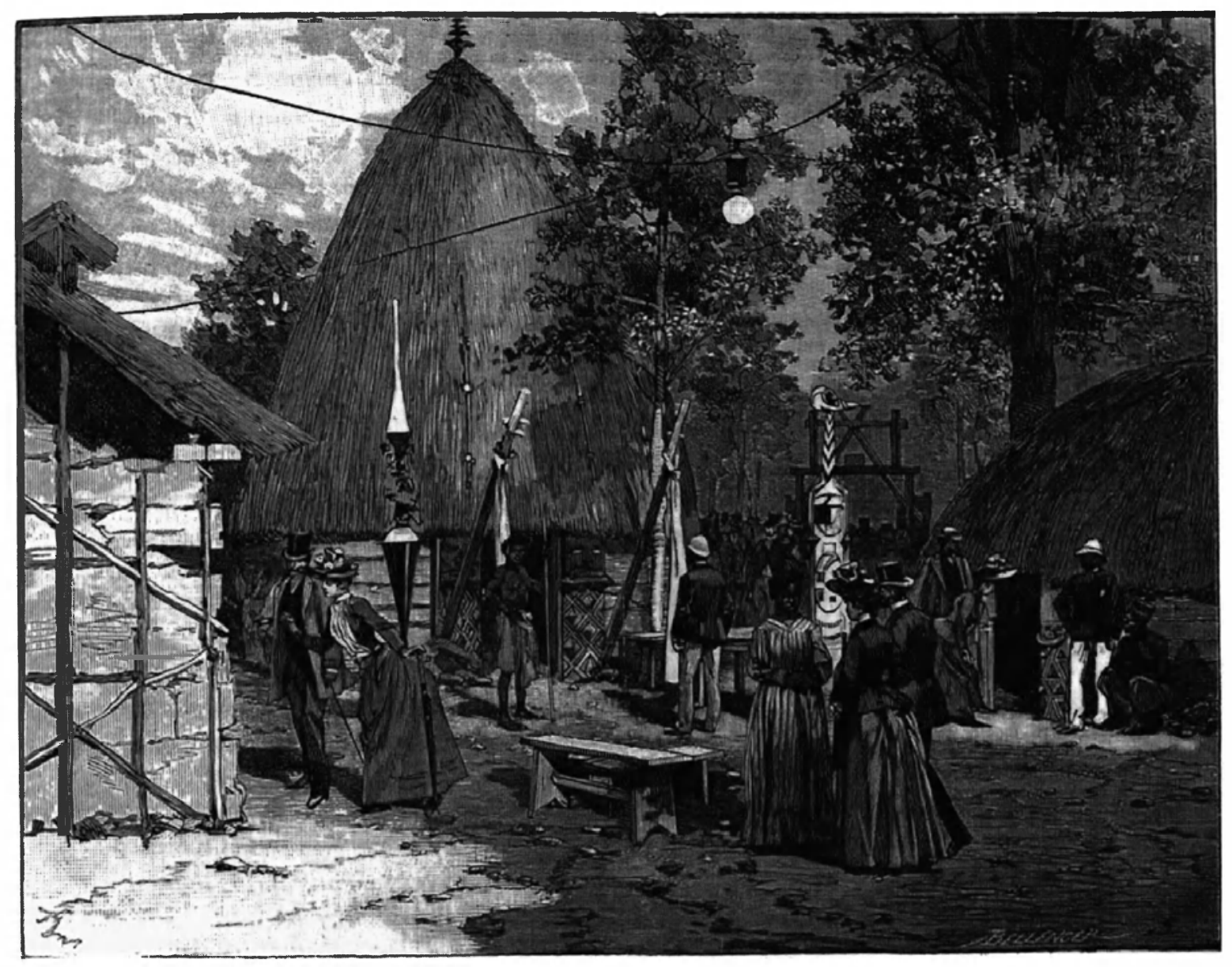


impulses are at their most intimate: "Nothing is farther from the ferocious spirit of despotism than the gentleness of that authority which looks more to the advantage of the one who obeys than to the utility of the one who commands" [73]. ${ }^{6}$

The Social Contract, too, argues for civil society as a substitute for the irrecoverable state of nature. ${ }^{7}$ Civil liberty, unlike natural freedom, is managed by way of a certain political knowingness that recognizes the historical fact of moral decline at the same time that it makes enlightened claims on the future. This liberty, then, has the curious double effect of turning civilized man into both a sublime subject/citizen of political reason and an agent of the corruptions that consistently frustrate reason:

Although in [civil society man] is deprived of several of the advantages belonging to him in the state of nature, he regains such great ones. His faculties are exercised and developed, his ideas are broadened, his feelings are ennobled, and his entire soul is elevated to such a height that, if the abuse of his new condition did not often lower his status to beneath the level he left, he ought constantly to bless the happy moment that pulled him away from it forever and which transformed him from a stupid, limited animal into an intelligent being and a man. [151; my emphasis]

It is because of this threat of private corruption that the preservation of the civil state comes to rely on the "general will." This is the work of the "republican imaginary": a sense of political community that resists the arbitrary power of private inclination and establishes a coherency of interests that it represents as the "common good" or "body politic." "The state or the city is merely a moral person whose life consists in the union of its members" [156]. If this union is to represent a legitimate rather than a tyrannical authority over its members, then each person must give himself, whole and entire, that is, equally, over to the general will. Yet it is the historical fact of inequality that has necessitated the social contract in the first place. The republican imaginary thus exposes its own sentimental history at the same time that it produces a "moral and collective body" [148] whose task is to overcome the sorrows of that history:

the first and most important consequence of the principles [of contract] is that only the general will can direct the forces of the state according to the purpose for which it was instituted, which is the common good. For if the opposition of private interests made necessary the establishment of societies, it is the accord of these same interests that made it possible. [153]

What is interesting is that the one form of inequality the contract cannot tolerate is slavery, precisely because it has no contractual logic: "To speak of a man giving himself in return for nothing is to speak of what is absurd, unthinkable; such an action would be illegitimate, void, if only because no one who did it could be in his right mind" [54]. Because the words

6. See also Eloisa 1: 89. St. Prieux comments on the community in the Swiss Upper Valais: "Simplicity subsists among themselves: when the children are once arrived at maturity, all distinctions between them and their parents seem to have ceased; their domestics are seated at the same table with their master; the same liberty reigns in the cottage as the republic, and each family is an epitome of the state."

7. In The Social Contract the little societies are refigured as "partial associations" which mediate the relationship of the individual to the state and prevent the proper articulation of the general will. In this context they interfere with the transcendence of private interest by a moral obligation to the common good. The family, nonetheless, is the prototype for political society. In a colony, where society is less developed and closer to the "simplicity of nature," the family might be seen to represent the state ["Of the First Societies," Basic Political Writings 142]. 
right and slavery are contradictory, the question of the right to enslave is a nonsensical one. This recalls Montesquieu's earlier objection to chattel slavery-namely that the division of goods cannot, according to the logic of civil law, rank the agents of division themselves among these goods. The fact that slavery is an ungrammatical proposition demands that it be erased from the republican imagination. Inequalities are tacitly recognized by the general will, but only insofar as they produce the conditions for association. The lack of sympathetic reciprocity and mutual obligation between master and slave strips their relationship of all moral significance [144]. As a concomitant of tyranny, then, slavery represents a failure of contract, a society where there is neither "a public good nor a body politic" [147], and hence a lapse in the grammar of sentimental republican language.

As the melancholy perception of the inevitable drawing away from nature, sentimentalism is innately preoccupied with the problem of inequality. The political shrewdness of a novel like Paul and Virginia has to do simultaneously with the reduction of the slave community (now consisting of named individuals) to the proportions of the family it serves and with the way in which slave ownership then slips into the more convenient category of familial patronage. Because the growing weight of slave numbers-and hence the increase in anonymous, alienated black faces on the island-represents both a problem of inequality with dimensions too large for sentimental concern and a glaring hiatus in the proposition of general will, slavery simply has to be put under sentimental erasure. The runaway slave whom Paul and Virginia rather improbably help by returning her to her master (and asking his forgiveness on her behalf) enters the collective affective memory as an agent of quite another pathos: The track on which the children accompany her assumes the signifying plenitude of Virginia's absence when Paul retraces it after her death. In a similar move, on the occasion of the family's self-commemoration (the mothers' name days) it is significantly not the slave but rather the poor creole who becomes the proper object of sentimental attention:

[she would send bread] to poor white families who, having been born on the island, had never tasted European bread, and who, without any blacks to help them and reduced to living in the woods on cassava roots, had neither the dullness that goes with slavery nor the courage that comes from education to help make their poverty bearable. [69]

Unless they are particularized, named, drawn into the family as pseudomembers (in which case they will love, rejoice, weep, and finally die just as and when their masters do) slaves have no place in this narrative. All they represent is an undifferentiated "dullness" which cannot inspire sympathy for the reason that slavery cannot be understood either in the "state of nature" or in the contractual terms of Rousseau's account of civil society. The imagined community can only be as large as the number of free, unalienated political subjects who represent it.

This whiting out of the colony is suggested in another sentimental scene where once again the histories of both master/slave relations and native culture are affectively erased. In the "native mime," or dramatization of biblical stories, which Virginia and Paul perform for their mothers, the family slaves too are actors. They play the reapers, or the shepherds of Midian. Curiously, despite the supposed native origins of this performance ("the white settlers lost no time in learning it themselves once they had seen it practised by the black children of the island" [67]), its value as an instrument of affective bonding 
has less to do with the relationship of creole community to indigenous culture than it does with the exiling of Mme de la Tour from Europe as the melancholy founding moment of this new colonial society: "reminded by this scene of her abandonment by her own family, her widowhood, the kind reception Marguerite had given her and their present hopes for a happy marriage between their children, [she] could not refrain from weeping" [68]. The mime provides an occasion for the collective shedding of tears, with the tropical Arcadian scene as a "natural" backdrop for the cementing of a sentimental contract. Once again the model is Rousseauean. In his Letter to M. D'Alembert, concerning the corrupting effects of theatrical representation, particularly in small communities-where it introduces luxury and inhibits trade [Letter 63] - Rousseau excepts the "periodical balls" or festivals at which old and young are brought into sensible contact. "These occasions for gathering in order to form unions and for arranging the establishment of families would be frequent means for reconciling divided families and bolstering the peace so necessary in our state" [131]. The theatrical scene (it is important that it is not an established theater but a ritual of performance which takes place in the woods) forecloses once again on history as it turns slave actors into biblical characters, while simultaneously the scene of spectatorhood organizes the colonizing shift from affective memory to affiliative bonding and the coming into being of a "little state."

But as Paul discovers, it is particularly the reading of novels that most powerfully expresses the fall from nature and the subsequent setting up of a recuperative community. "The great authors," the old man tells him, "have always appeared in those times which all societies find most difficult to bear, times of barbarism and of depravity" [PV 113]. When Paul laments the failure of virtue in romance fiction, his instructor responds by pointing out not only literature's powers of consolation but more importantly its function as the exemplification of morality and restraint. It is through reading and writing that the little (literary) society can know and define itself in and against an unhappy world: "Read then, my son. The wise men who have written are travellers who have gone before us in the paths of adversity. They stretch forth their hands and invite us to join their company when all else has forsaken us. A good book is a good friend" [113]. Little wonder then that Paul should prefer the reading of novels to the studies of geography and history, both of which represent only a disordered series of calamities and divisions. Not only do novels stimulate again that affective response by means of which social bonds are tied and retied, but at the same time they reduce the moral chaos of the outside world to a moment of local, internalized loss which provides the community with a sense of its own sympathetic dimensions. Reading itself is a social activity, not a private and corrupting one, as the opponents of old-world sentimentalism would have it: While reading aloud to his mother(s), Paul's memories of Virginia (now "exiled" in Europe) are reawakened, "his voice become[s] choked and tears fall from his eyes" [91]. Although he is "thrown into confusion" by the "fashionable" novels that reflect European licentiousness, these too become the occasion for a collective remembering that can stand against the European "forgetting" to which he fears Virginia may fall victim. At every affective turn-the figuring of Virginia as victim of misfortune, which her wisdom and tenderness overcome, or of corruption against which she lacks defense - the little community is consolidated by a sense of itself as non-European. Virginia is at first sent away "for the good of the whole family" [89] and in order to secure a better future for the lovers, who must be protected against their youthful desires. Yet the threat that feminine sexual awakening represents to the family from within, rapidly externalizes itself as the corrupting power of Europe once Virginia is banished: hence the real need for her expulsion. It is the means by which private loss can be turned into sentimental gain and hence by which society can identify itself again with pure virtue, although this time in the worldly rather than the pastoral sense. Paul's hitherto "Creole indifference" to the world becomes a sentimental knowingness when he and Virginia (now melancholy in their separation) learn to read and 
write: Paul studies geography and history and, most importantly, discovers the consolations of philosophy. "Love [is] his motive in these studies" [90]. This in turn becomes a way of inscribing the colony that is not-Europe onto the absolute nature that the novel as novel can never quite recover (as the preface, with its disclaiming of "pastoralism," makes abundantly clear) and at the same time committing this history to a powerful act of memory: "No marble was raised over their humble mounds, no inscription was cut to their virtues, but their memory has remained indelible in the hearts of those who experienced their kindness" [136]. This memory too is assertively non-European and antimonarchical. Paul and Virginia are mourned by a sentimental republic: "The voice of the people, which says nothing of the monuments raised to the glory of kings, has given names to some parts of this island which will perpetuate the memory of Virginia's loss" [136].

It is thus at the point at which the island attains its colonial status-recognizing its place in the world as an inheritance from a Europe from which it nonetheless remains separate - that the story of Paul and Virginia comes out into the political world as a novel: both the product and the ordering of a worldly melancholy. The novel is brought to life by a community of bereft readers and writers. As the voice of the only living memory of this community, the old man's narrative is produced by an enabling loss; the narrator becomes its representative audience by virtue of his exposure to and his recognition of "worldly prejudices" [40]. Saint-Pierre's preface confesses to the need for an affected, experienced reading, a sense of virtue lost as the means by which virtue (and wisdom) might be gained, in order that the novel and the model society it represents can come into (publishable) being:

When some years ago, I had made a very imperfect sketch of this species of pastoral, I asked if I might read it to a beautiful lady who was much received in wealthy and distinguished society, and to some grave men who lived far from it, so that I might form an idea of the effect it would produce on readers of such different kinds. I had the satisfaction of seeing them all shed tears. [37]

Here once again there are unmistakable echoes of Rousseau's $J$ ulie, where the author's preface asserts the inevitability of epistolary novelization in the face of lost virtue ("I saw the manners of the times, and have published these letters" [preface v]). InJulie, too, the literary response to (particularly) Parisian decadence is to set the scenes of affective redemption in the "little republics" of the Upper Valais or Clarens. There the controlled cast of characters come increasingly, as Wolmar asserts, to stand for the new contractual possibilities of friendship:

He attached himself to me with that zealous friendship which it was impossible for me not to return, and from that time we formed connections which have everyday grown stronger. I discovered in this new state of mind, that interest is not always, as I had supposed, the sole motive which influences human conduct, and that among the crowd of prejudices which [oppose] virtue, there are likewise some which [favor] it. [2: 309]

The fact that Wolmar's sentimental elite is forged out of a combination of independent wills and that it gives a measure of coherence to the muddle of private motives and passions that inspire human activity, demonstrates the recuperative power of novelized affection. Wolmar aggressively and insistently befriends St. Prieux, drawing him into the community, which his desire for Julie has violated. This contracting of desire and its transformation into virtue become the principal interest of the novel. The divisive force of passion is finally overcome by Julie's death, when her lover is invited to join in the 
companionship of common affliction: "Oh come, you who partake of my loss! Come partake of my griefs. Come cherish my heart with your sorrow. This is the only consolation I can hope for; the only pleasure I can taste" [3:302]. As passionate intimacy is transformed first into social virtue and then into collective mourning, the series of epistolary exchanges begin to assume the cohesiveness of a novel, not least because the sentimental congregation of "dear and respectable friends" [303] assumes the status of an affected readership. The "Rousseau" who in his footnotes has hitherto anticipated the reader's irritation with the suppression of certain crucial letters and the unedited repetitions, which suggest a lack of concern for his readers' interest, makes a parting confession to the readerly pleasure he believes this epistolary "novel" offers:

After having read these letters several times over, I think I have discovered the reason why the interest which I imagine every well-disposed reader will take in them, though perhaps not very great, is yet agreeable: and this is because ... it is not excited by villainies or crimes, nor mixed with the disagreeable sensations of hatred. [304]

The spectacle of Julie's tomb, like that of Virginia's "humble mound," encourages a mimesis of virtue which links exemplary heroine to familial community, to St. Prieux as the reader of Claire's letter, to Rousseau as reader of the collection and finally to the (again exemplary) reading audience that his footnotes frame. The little society this novel addresses (and by whose agency the book becomes a novel of sentiment) are those "welldisposed reader[s]" or "dear and respectable friends" whom Claire apostrophizes in her final letter to St. Prieux:

Let us assemble all that was dear to her: let her spirit animate us; let her heart unite ours; let us live continually under her eye. I take a delight in conceiving that her amiable and susceptible spirit will leave its peaceful mansion to revisit ours; that it will take a pleasure in seeing its friends imitate her virtues . . . in seeing them kiss her tomb, and sigh at the repetition of her name. [3: 409]

So in the case of Julie, as of Paul and Virginia, the novel is brought into being by the very community of readers it represents. Both reading and republicanism are acts of commemorative mourning, "giv[ing] lustre to obscure virtue, consol[ing] the unfortunate ... serv[ing] as a bulwark against error and tyranny" [PV.106-07]. In Paul and Virginia the melancholy of the novel opens up a space that might be called colonial: a calling into memory of pure virtue, whose loss marks the place of sensible bonding and republican contract. It is for this reason that slavery simply cannot feature in the self-dramatization of this novel. Too large an issue to be read sentimentally, the problem of slavery points to this little society's contractual difference from itself. To draw attention to the historical, economic, and political status of the negro characters on the lle de France would be to force the novel to open itself up to the complexities of antiabolitionist colonial history, rather than allowing it to offer to an old empire, as it endeavors to do, a model of both exemplificatory correction and critique.

\section{WORKS CITED}

Benot, Yves. La Révolution française et la fin des colonies. Paris: La Découverte, 1988. Biondi, Jean-Pierre, and François Zuccarelli. 16 Pluviose An II: Les colonies de la Revolution. Paris: Denoel, 1989.

Davis, David Brion. The Problem of Slavery in the Age of Revolution, 1770-1823. Ithaca, NY: Cornell UP, 1975. 
Goodden, Angelica. "Tradition and Innovation in Paul et Virginie: A Thematic Study." Modern Language Review 77(July 1982): 558-67.

Nwulia, Moses D. E. The History of Slavery in Mauritius and the Seychelles, 1810-1875. London: Associated University Presses, 1981.

Rousseau, Jean Jacques. Discourse on the Origins of Inequality; On The Social Contract. Jean Jacques Rousseau: The Basic Political Writings. Ed. and trans. Donald A. Cress. Indianapolis: Hackett, 1987.

_. Eloisa: A Series of Original Letters [Julie, ou La nouvelle Héloise]. Translated from the French. 3 vols. London: John Harding, 1810.

-Politics and the Arts: Letter to M. D'Alembert on the Theatre. Trans. Allan Bloom. Glencoe, IL: Free Press, 1960.

Saint-Pierre, Jacques-Henri-Bernardin de. Paul and Virginia. Trans. John Donovan. Harmondsworth: Penguin, 1989. [PV] 